\title{
Microbiologic characteristics and antibiotic resistance rates of diabetic foot infections
}

\section{Perfil microbiológico e de resistência bacteriana no pé diabético infectado}

Dênisson Guedes Pontes"; Ivan Tramujas da Costa e Silva, TCBC-AM1,2,3; Jessica Jansen Fernandes"; Amanda de Fátima Gurgel Monteiro4; Pedro Henrique da Silva Gomes4; Maria Gabriela Monteiro Ferreira, AcCbC-AM4; Flávia Guerreiro de Lima5; Jessica de Oliveira Correia ${ }^{4}$; Neivaldo José Nazaré dos Santos ${ }^{6,7}$; Leonardo Pessoa Cavalcante, TCBC-AM $1,2,6$ (D.

\section{A B S T R A C T}

\begin{abstract}
Purpose: the purpose of this research was to identify the sociodemographic and microbiological characteristics and antibiotic resistance rates of patients with diabetic foot infections, hospitalized in an emergency reference center. Methods: $i t$ was an observational and transversal study. The sociodemographic data were collected by direct interview with the patients. During the surgical procedures, specimens of tissue of the infected foot lesions were biopsied to be cultured, and for bacterial resistance analysis. Results: the sample consisted of 105 patients. The majority of patierns were men, over 50 years of age, married and with low educational level. There was bacterial growth in 95 of the 105 tissue cultures. In each positive culture only one germ was isolated. There was a high prevalence of germs of the Enterobacteriaceae family (51,5\%). Gram-negative germs were isolated in $60 \%$ of cultures and the most individually isolated germs were the Gram-positive cocci, Staphylococcus aureus (20\%) and Enterococcus faecalis (17,9\%). Regarding antibiotic resistance rates, a high frequency of Staphylococcus aureus resistant to methicillin $(63,0 \%)$ and to ciprofloxacin $(55,5 \%)$ was found; additionally, $43,5 \%$ of the Gram-negative isolated germs were resistant to ciprofloxacin. Conclusions: the majority of patients were men, over 50 years of age, married and with low educational level. The most prevalent isolated germs from the infected foot lesions were Gramnegative bacteria, resistant to ciprofloxacin, and the individually most isolated germ was the methicillin resistant Staphylococcus aureus.
\end{abstract}

Keywords: Diabetic Foot. Microbiota. Anti-Bacterial Agents. Drug Resistance, Bacterial.

\section{INTRODUCTION}

$\mathrm{D}$ iabetes Mellitus (DM) is currently one of the most prevalent diseases in the world, with about 425 million people affected and with an increase forecast to about 642 million over the next 20 years. In Brazil, in 2017, there were about 12.5 million people between 20 and 79 years of age with DM, with an estimated increase to 20.3 million by the year 2045. It is believed that the increase in the prevalence of DM is due to population aging, greater urbanization and increase in sedentary lifestyle, concomitantly leading to the increase in obesity in the Brazilian population".

An important problem of DM is the morbidity resulting from its complications. Peripheral neuropathy and circulatory complications are highly prevalent, manifesting clinically through the appearance of foot ulcers. Patients with DM are 15 25\% likely to have foot ulceration throughout their lives ${ }^{2,3}$.

Foot ulcers start as a result of peripheral neuropathy, which, associated with the decreased neuroendocrine response and sometimes with atherosclerotic peripheral arterial disease, culminates in the appearance of ulcerations and secondary infection ${ }^{4}$.

1 - Universidade Federal do Amazonas, Programa de Pós-Graduação (Mestrado Profissional) em Cirurgia - PPGRACl - Manaus - AM, Brasil 2 - Universidade Federal do Amazonas, Departamento de Clínica Cirúrgica da Faculdade de Medicina - Manaus - AM, Brasil 3 - Universidade Federal do Amazonas, Hospital Universitário Getúlio Vargas - Serviço de Cirurgia Geral - Manaus - AM, Brasil 4 - Universidade do Estado do Amazonas, Faculdade de Medicina - Manaus - AM, Brasil 5 - Universidade Federal do Amazonas, Faculdade de Medicina - Manaus - AM, Brasil 6 - Universidade Federal do Amazonas, Hospital Universitário Getúlio Vargas - Serviço de Cirurgia Vascular - Manaus - AM, Brasil 7 - Universidade do Estado do Amazonas, Departamento de Clínica Cirúrgica da Faculdade de Medicina - Manaus - AM, Brasil 
Wounds are often initially colonized by microorganisms from the surrounding skin microbiota, the main pathogens responsible for infections usually being Staphylococcus aureus and Streptococcus spp. ${ }^{5}$.

In most severe cases requiring antibiotic therapy, it is necessary to start them empirically, at the moment of diagnosis. Subsequently, daily clinical evaluations and the result of culture and antibiogram allow adjustment to the suitable antimicrobial therapy ${ }^{3,6}$.

Routine culture and antibiogram exams in a certain hospital allows knowledge of the microbiota of that population, subsidizing the development of local guidelines for initial empirical antibiotic therapy, promoting direct impact on treatment success, and even reducing costs, with a stepwise and more logical use of antimicrobials ${ }^{7,8}$. The inappropriate use of antimicrobials during the treatment of diabetic foot infections can aggravate the infection and even lead to the development of bacterial resistance ${ }^{9}$.

In the state of Amazonas, there is lack of studies that analyze the microbiological characteristic and bacterial resistance of infections in foot injuries of diabetic patients. In view of this knowledge gap, we set out to analyze the sociodemographic and microbiological aspects of patients with infected diabetic foot, hospitalized in a reference hospital in the State of Amazonas.

\section{METHODS}

Through a prospective, observational, crosssectional, descriptive, prevalence study, we evaluated the microbiological characteristic and bacterial resistance of patients admitted to the Hospital 28 de Agosto, in the period from March to August 2018. The injuries were podal and infected. The study protocol was approved by the Ethics in Research Committee on Human Beings at the Federal University of Amazonas (No. 2.335.126).

The sample consisted of patients with DM, with infected foot lesions (infected diabetic foot), who sought emergency care through the Brazilian Unified Health System (SUS) in the vascular surgery department of the Hospital 28 de Agosto, in Manaus, capital of the state of Amazonas. We included patients of both sexes, over 18 years old, and who formally agreed to participate in the research.

We interviewed patients eligible to enter the survey using a form on demographic data, comorbidities, physical examination, and classification of infection severity. In a second step, we added the results of culture and antibiogram tests of fragments of deep tissues harvested during the first surgical procedure of the studied participant. We also recorded the type of surgical procedure performed, complications, length of hospital stay, and deaths.

During surgical procedures performed in the operating room, under anesthesia and with antisepsis and asepsis care, such as abscess drainage, debridement and amputations, we collected a tissue fragment approximately $2 \mathrm{~cm}$ long at the greater axis, immediately after debridement of devitalized tissues and irrigation of the wound with saline, as recommended by Sotto et al. ${ }^{10}$ and Lipsky et al. ${ }^{11}$. We conditioned the biological specimens in vials with sterilized saline and sent them for culture and antibiogram.

The sociodemographic variables were age, sex, origin, marital status, education and occupation, to characterize the epidemiological characteristics of the studied population. We studied the clinical status during the interview by searching for the variables hypertension, peripheral arterial disease, chronic kidney disease, hemodialysis, dyslipidemia, smoking, previous hospitalizations, and previous use of antimicrobial agents. To classify wounds, we used the Wagner's and the PEDIS (Perfusion, Extent / Size, Depth / Tissue Loss, Infection, Sensation) ${ }^{11}$ classifications. We identified the surgical procedures as debridements, minor amputations (with heel preservation) and major amputations (above the ankle). We also recorded the length of stay and the number of in-hospital deaths.

We performed the statistical analysis with simple and absolute frequencies, using the Shapiro-Wilk test for quantitative data and the Pearson's chi-square test for qualitative variables, with a significance level of $5 \%$.

\section{RESULTS}

The study sample consisted of 105 patients with complete data collection forms and with biological 
material obtained for microbiological analysis.

Regarding the sociodemographic characteristics, there was a predominance of male patients, aged between 50 and 70 years old, married, with low level of education and from the city of Manaus (Table 1).

Table 1. Distribution of sociodemographic variables of patients.

\begin{tabular}{|c|c|c|}
\hline Variables $(n=105)$ & fi & $\%$ \\
\hline \multicolumn{3}{|l|}{ Sex } \\
\hline Female & 43 & 40.0 \\
\hline Male & 63 & 60.0 \\
\hline \multicolumn{3}{|l|}{ Age (years) } \\
\hline $30 \mid---39$ & 6 & 5.7 \\
\hline $40 \mid---49$ & 23 & 21.9 \\
\hline $50 \mid---59$ & 31 & 29.5 \\
\hline $60 \mid---69$ & 28 & 26.7 \\
\hline 70 |--- 79 & 15 & 14.3 \\
\hline $80 \mid---89$ & 2 & 1.9 \\
\hline Mean + Sd & $57.8 \pm 11.6$ & \\
\hline \multicolumn{3}{|l|}{ Educational level } \\
\hline $\begin{array}{l}\text { Elementary/Middle } \\
\text { school }\end{array}$ & 61 & 58.1 \\
\hline High school & 35 & 33.3 \\
\hline College & 9 & 8.6 \\
\hline \multicolumn{3}{|l|}{ Marital Status } \\
\hline Married & 54 & 51.4 \\
\hline Single/divorced & 37 & 35,2 \\
\hline Widower & 14 & 13.3 \\
\hline \multicolumn{3}{|l|}{ Profession } \\
\hline Retired & 32 & 30.5 \\
\hline Freelance & 26 & 24.8 \\
\hline Domestic & 10 & 9.5 \\
\hline Formal job & 20 & 19.1 \\
\hline Informal job & 10 & 9.5 \\
\hline Unemployed & 7 & 6.7 \\
\hline \multicolumn{3}{|l|}{ Origin } \\
\hline Capital & 67 & 63.8 \\
\hline Countryside & 35 & 33.3 \\
\hline Other state & 3 & 2.9 \\
\hline
\end{tabular}

Considering the clinical data and comorbidities (Table 2), there was a high prevalence of hypertension, as well as dyslipidemia. Peripheral arterial disease was present in $27.6 \%$ of patients.

Table 2. Clinical variables of patients.

\begin{tabular}{|c|c|c|}
\hline Variables $(n=105)$ & $\mathrm{fi}$ & $\%$ \\
\hline Insulin-dependent & 46 & 43.8 \\
\hline $\begin{array}{l}\text { Chronic kidney disease on } \\
\text { dialysis }\end{array}$ & 3 & 2.9 \\
\hline Dyslipidemia & 48 & 45.7 \\
\hline Peripheral arterial disease & 29 & 27.6 \\
\hline Hypertension & 59 & 56.2 \\
\hline Chronic kidney disease & 13 & 12.4 \\
\hline $\begin{array}{l}\text { Osteomyelitis on } \\
\text { radiography }\end{array}$ & 40 & 38.1 \\
\hline \multicolumn{3}{|l|}{ Lesion location } \\
\hline Right limb & 58 & 55.2 \\
\hline Left limb & 47 & 44.6 \\
\hline \multicolumn{3}{|l|}{ Surgical procedure } \\
\hline Major amputation* & 7 & 6.7 \\
\hline $\begin{array}{r}\text { Minor } \\
\text { amputation** }\end{array}$ & 56 & 53.3 \\
\hline Debridement & 42 & 40.0 \\
\hline Previous antibiotic use & 62 & 59.0 \\
\hline Previous hospitalization & 54 & 51.4 \\
\hline Death & 5 & 4.8 \\
\hline
\end{tabular}
Hospitalization period

(days)

$$
\text { Q1 - Median - Q3 10-16-26 }
$$

Smoking $17 \quad 16.2$

fi = absolute frequency; \% = percentage; Qi = quartiles; * major amputation = amputation above the ankle; ${ }^{*}$ minor amputation = amputation at foot level (with ankle preservation).

All patients underwent radiological examination of the affected foot, with presence of radiological osteomyelitis in 40 patients (38.1\%).

When analyzing the type of surgical procedure, just over half the patients underwent minor amputations (with heel preservation), $40 \%$ of them underwent surgical debridement, and seven patients (6.5\%), major amputations (Table 2).

There were five deaths (4.8\%), septic shock being the most recorded cause. The median length of hospital stay was 16 (10-26) days (Table 2). 
Considering the distribution of injuries severity according to the PEDIS and Wagner classifications (Figures 1 and 2), there were no injuries characterized as Grades 0 and 1 by either one, since the sample was composed exclusively of patients with infected diabetic foot who demanded surgical treatment. As for the PEDIS classification, we found a higher prevalence of Grade 3 injuries (79.0\%); as for the Wagner's one, there was a higher prevalence of Grade 2 (54.3\%) and Grade 3 injuries (34.3\%).

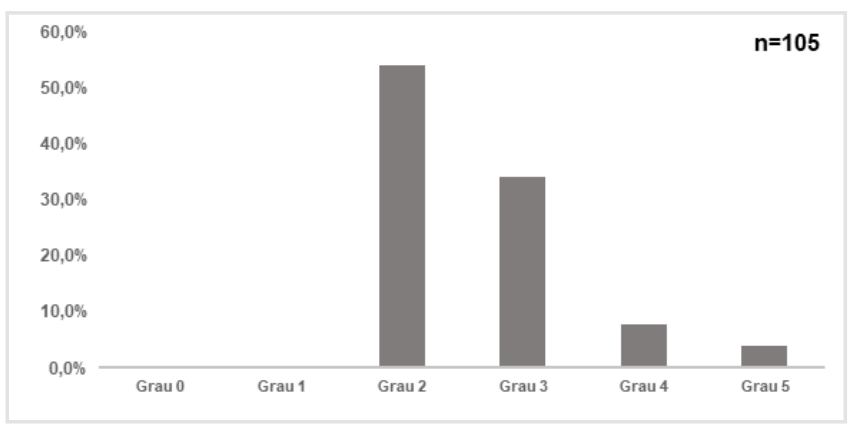

Figure 1. Distribution of foot lesions according to the "Perfusion, Extent I Size, Depth / Tissue Loss, Infection, Sensation" classification (PEDIS).

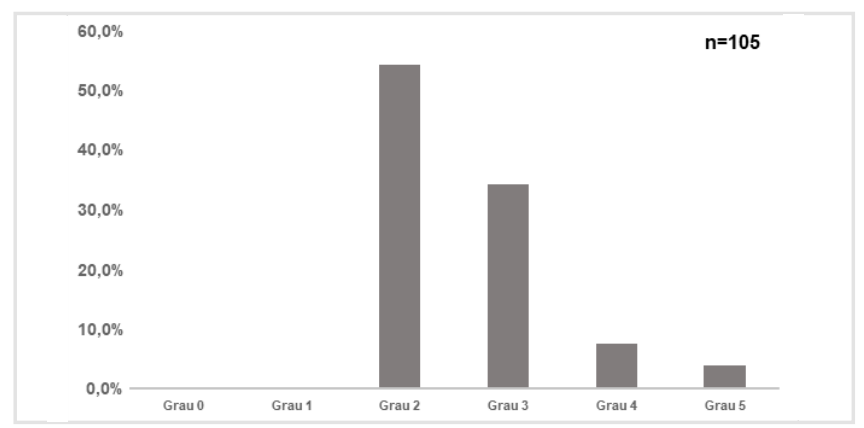

Figure 2. Distribution of foot lesions according to the classification of Wagner.

Of the 105 samples of tissue fragments collected for culture and susceptibility testing, 95 were positive for growth of a single germ. There was a predominance of Gram-negative bacteria from the Enterobacteriaceae family (51.5\%) and a low incidence of Gram-negative bacteria from the Pseudomonadaceae family (4.2\%). Among the Gram-positive bacteria isolated, there was a higher incidence of germs from the Staphylococcaceae and Enterococcaceae families.

Although the group of Gram-negative enterobacteria was more prevalent, the germs most frequently isolated in this study were the Gram-positive
S. aureus (20.0\%) and Enterococcus faecalis (17.9\%). Proteus mirabilis $(12.6 \%)$ and Klebsiella pneumoniae $(10.5 \%)$ were the most isolated Gram-negative specimens, whereas Pseudomonas aeruginosa showed a low incidence $(4.2 \%)$ in this population (Table 3 ).

Table 3. Distribution of culture results according to isolated germ.

\begin{tabular}{|c|c|c|}
\hline Isolated germ $(n=95)$ & $\mathrm{fi}$ & $\%$ \\
\hline Achromobacter xylosoxidans & 1 & 1.1 \\
\hline Citrobacter freundii & 2 & 2.1 \\
\hline Citrobacter youngae & 1 & 1.1 \\
\hline $\begin{array}{l}\text { Complexo de Enterobacter } \\
\text { cloacae }\end{array}$ & 2 & 2.1 \\
\hline $\begin{array}{l}\text { Enterobacter cloacae ssp } \\
\text { cloacae }\end{array}$ & 1 & 1.1 \\
\hline Enterococcus avium & 1 & 1.1 \\
\hline Enterococcus faecalis & 17 & 17.9 \\
\hline Enterococcus faecium & 1 & 1.1 \\
\hline Escherichia coli* & $\left(4^{*}\right) 6$ & 6.3 \\
\hline Klebsiella oxytoca & 4 & 4.2 \\
\hline Klebsiella pneumoniae* & $\left(4^{*}\right) 10$ & 10.5 \\
\hline $\begin{array}{l}\text { Morganella morganii ssp. } \\
\text { Morganii }\end{array}$ & 5 & 5.3 \\
\hline Proteus mirabilis & 12 & 12.6 \\
\hline Proteus penneri & 4 & 4.2 \\
\hline Providencia stuartii & 1 & 1.1 \\
\hline Pseudomonas aeruginosa & 4 & 4.2 \\
\hline Serratia marcescens & 1 & 1.1 \\
\hline Staphylococcus aureus** & $(12 * *) 19$ & 20.0 \\
\hline Staphylococcus saprophyticus & 1 & 1.1 \\
\hline $\begin{array}{l}\text { Stenotrophomonas } \\
\text { maltophilia }\end{array}$ & 1 & 1.1 \\
\hline Streptococcus agalactiae & 1 & 1.1 \\
\hline
\end{tabular}

fi = absolute frequency; \% = percentage; ${ }^{*}=$ frequency of ESBL (extended spectrum beta-lactamase); ** = frequency of MRSA (methicillin-resistant S. aureus).

Regarding the bacterial resistance in vitro, we found high rates of $\mathrm{S}$. aureus resistant to methicillin $(63.2 \%)$ and to ciprofloxacin $(55.5 \%)$, and $43.5 \%$ of Gram-negative bacteria were resistant to ciprofloxacin. P. aeruginosa, as well as all other Gram-negative bacteria, were sensitive to carbapenems. We highlight the presence of four strains of Klebsiella pneumoniae 
and four strains of Escherichia coli that were multi-drug resistant organisms (MDRO), with positive extended spectrum beta-lactamase (ESBL), as well as 12 strains of methicillin-resistant S. aureus (MRSA) (Tables 4 and 5).

\section{DISCUSSION}

We found a sociodemographic characteristic that was mainly characterized by men, with a predominant age group between 50 and 70 years old, retired, married, with low level of education, and living in the city of Manaus. Bona et al. ${ }^{12}$, in an epidemiological study conducted in Fortaleza, capital of Ceara State, retrospectively analyzed 67 medical records of patients hospitalized for infected diabetic foot, and found a higher frequency of female patients (52\%), with an age range similar to that found in the present study, and also observed a higher frequency of patients from the state capital. Pedras et al. ${ }^{13}$, studying 206 diabetic patients with indication for amputation, observed a majority of male patients, with an average age of 66 years, married and with low education, characteristics similar to those found in the present study. Such aspects indicate that the sociodemographic variables can exert a significant role both in the prevalence and in the evolution of the diabetic foot. Low socioeconomic level, low education and lack of family support may be predisposing factors to the complications of DM and that can contribute to increased risk of lower extremity amputations ${ }^{14}$.
Table 4. Distribution of bacterial resistance profile of the most prevalent Gram-positive germs.

\begin{tabular}{|c|c|c|c|c|}
\hline $\begin{array}{l}\text { Gram-positive } \\
\text { germs }\end{array}$ & \multicolumn{2}{|c|}{$\begin{array}{c}\text { Staphylococcus } \\
\text { aureus }\end{array}$} & \multicolumn{2}{|c|}{$\begin{array}{l}\text { Enterococcus } \\
\text { faecalis }\end{array}$} \\
\hline Antibiotics & $\begin{array}{c}\text { n - resistant } \\
\text { / total } \\
\text { isolated }\end{array}$ & $\%$ & $\begin{array}{c}\mathrm{n} \text { - } \\
\text { resistant } \\
\text { / total } \\
\text { isolated }\end{array}$ & $\%$ \\
\hline Ampicillin & -- & -- & $0 / 17$ & 0 \\
\hline $\begin{array}{l}\text { Ampicillin/ } \\
\text { Sulbactam }\end{array}$ & -- & -- & $0 / 17$ & 0 \\
\hline Fusidic Acid & $0 / 19$ & 0 & -- & -- \\
\hline Benzy|penicillin & $19 / 19$ & 100 & $0 / 17$ & 0 \\
\hline Ciprofloxacin & $10 / 18$ & 55.5 & -- & -- \\
\hline Clindamycin & $12 / 19$ & 63.15 & -- & -- \\
\hline Daptomycin & $0 / 19$ & 0 & $0 / 17$ & 0 \\
\hline Erythromycin & $14 / 19$ & 78.94 & -- & -- \\
\hline Gentamycin & $1 / 19$ & 5.26 & $2 / 17$ & 11.76 \\
\hline Linezolid & $0 / 19$ & 0 & $0 / 17$ & 0 \\
\hline Oxacillin & $12 / 19$ & 63.15 & -- & -- \\
\hline Rifampicin & $15 / 19$ & 47.36 & -- & -- \\
\hline Teicoplanin & $0 / 19$ & 0 & $0 / 17$ & 0 \\
\hline $\begin{array}{l}\text { Trimetropim } \\
\text { Sulfamethoxazole }\end{array}$ & $0 / 19$ & -- & -- & -- \\
\hline Vancomycin & $0 / 19$ & 0 & $1 / 17$ & 5.88 \\
\hline
\end{tabular}

Table 5. Distribution of bacterial resistance profile of the most prevalent Gram-negative germs.

\begin{tabular}{|c|c|c|c|c|c|c|c|c|c|c|}
\hline \multirow{2}{*}{$\begin{array}{l}\text { Gram- negative } \\
\text { germs } \\
\text { Antibiotics }\end{array}$} & \multicolumn{2}{|c|}{$\begin{array}{l}\text { Proteus } \\
\text { mirabilis }\end{array}$} & \multicolumn{2}{|c|}{$\begin{array}{c}\text { Klebsiella } \\
\text { pneumoniae }\end{array}$} & \multicolumn{2}{|c|}{ Escherichia coli } & \multicolumn{2}{|c|}{$\begin{array}{c}\text { Morganella } \\
\text { morganii }\end{array}$} & \multicolumn{2}{|c|}{$\begin{array}{c}\text { Pseudomonas } \\
\text { aeruginosa }\end{array}$} \\
\hline & $R^{*} / N^{* *}$ & $\%$ & $\begin{array}{l}\text { Escherichia } \\
\text { coli }\end{array}$ & $\%$ & & $\%$ & $\mathrm{R} / \mathrm{N}$ & $\%$ & & \\
\hline Amikacin & $0 / 12$ & 0 & & 0 & $0 / 6$ & 0 & $0 / 5$ & 0 & $1 / 4$ & 25 \\
\hline Amikacin & $6 / 12$ & 50 & $5 / 10$ & 50 & $6 / 6$ & 100 & $5 / 5$ & 100 & -- & -- \\
\hline $\begin{array}{l}\text { Ampicillin/ } \\
\text { Sulbactam }\end{array}$ & $4 / 12$ & 33,3 & $5 / 10$ & 50 & $5 / 6$ & 83,3 & $4 / 5$ & 80 & -- & -- \\
\hline Ceftriaxone & $4 / 12$ & 33,3 & $4 / 10$ & 40 & $2 / 6$ & 33,3 & $1 / 5$ & 20 & -- & -- \\
\hline Cefepime & $3 / 12$ & 25 & $3 / 10$ & 30 & $1 / 6$ & 16,6 & $0 / 5$ & 0 & $1 / 4$ & 25 \\
\hline Cefoxitin & $0 / 12$ & 0 & 0/10 & 0 & $1 / 6$ & 16,6 & $3 / 5$ & 60 & -- & -- \\
\hline
\end{tabular}




\begin{tabular}{|c|c|c|c|c|c|c|c|c|c|c|}
\hline Ceftazidime & $2 / 12$ & 16,6 & $2 / 10$ & 20 & $0 / 6$ & 0 & $2 / 5$ & 40 & $2 / 4$ & 50 \\
\hline Cefuroxime & $6 / 10$ & 60 & $4 / 10$ & 40 & $5 / 6$ & 83.3 & $3 / 5$ & 60 & -- & -- \\
\hline $\begin{array}{l}\text { Axetil } \\
\text { Cefuroxime }\end{array}$ & $6 / 10$ & 60 & $4 / 10$ & 40 & $5 / 6$ & 83.3 & $2 / 5$ & 40 & -- & -- \\
\hline Ciprofloxacin & $4 / 12$ & 33.3 & $5 / 10$ & 50 & $5 / 6$ & 83.3 & $4 / 5$ & 80 & $2 / 4$ & 50 \\
\hline Colistin & -- & -- & $0 / 10$ & 0 & -- & & -- & -- & -- & -- \\
\hline Ertapenem & $0 / 12$ & 0 & $0 / 10$ & 0 & $0 / 6$ & 0 & $0 / 5$ & 0 & -- & -- \\
\hline Gentamycin & $3 / 12$ & 25 & $3 / 10$ & 30 & $0 / 6$ & 0 & $1 / 5$ & 20 & $1 / 4$ & 25 \\
\hline Imipenem & -- & -- & $0 / 10$ & 0 & $0 / 6$ & 0 & $2 / 5$ & 40 & $0 / 4$ & 0 \\
\hline Levofloxacin & -- & -- & -- & -- & -- & -- & -- & -- & -- & -- \\
\hline Meropenem & -- & -- & $0 / 10$ & 0 & $0 / 6$ & 0 & $0 / 5$ & 0 & $0 / 4$ & 0 \\
\hline Minocycline & -- & -- & -- & -- & -- & -- & -- & -- & -- & -- \\
\hline $\begin{array}{l}\text { Piperacillin/ } \\
\text { Tazobactam }\end{array}$ & $1 / 12$ & 8.3 & $3 / 10$ & 30 & $0 / 6$ & 0 & $0 / 5$ & 0 & $2 / 4$ & 50 \\
\hline Tigecycline & $0 / 12$ & 0 & -- & -- & $0 / 6$ & 0 & -- & -- & -- & -- \\
\hline
\end{tabular}

According to the 7th Brazilian Guideline for Hypertension, the prevalence of hypertension is estimated between 50 and $75 \%$ in patients with $\mathrm{DM}^{15}$. In the present study, hypertension was the most prevalent comorbidity $(56.2 \%)$, within the range estimated by that guideline.

Hinchliffe et al. ${ }^{16}$ found that peripheral arterial disease in diabetic patients with foot ulcers reaches $50 \%$ of frequency, which negatively impacts the capacity for tissue regeneration of these patients' extremities, resulting in high rates of amputations. In the present study, peripheral arterial disease was present in $27.6 \%$ of patients. We believe that peripheral arterial disease, associated with infection, was responsible for the high amputation rate.

In our series, there was a non-negligible mortality, close to $5 \%$. Assuming that these deaths were due to systemic infection whose primary focus was the foot injury, since the reason for hospitalization was infected foot injury, we can infer that the prevention of initial foot injuries is of utmost importance. This is fully reachable with simple prophylactic measures, through adequate orientation, made in primary care level, already well established in clinical guidelines ${ }^{11}$. In addition, compliance to such guidelines could ultimately have avoided these deaths, as well as the amputations that left sequelae in the survivors.

The most frequent surgical procedures performed were amputations (60\%), with a predominance of minor amputations (53.3\%). Schaper et al. ${ }^{17}$, in a prospective European multicenter study with 1,232 patients, hospitalized and outpatient ones, found an amputation rate of $23 \%$ and a death rate of $6 \%$. We believe that the highest amputation rate we found was because we only analyzed hospitalized patients, therefore with more severe injuries.

We used the Wagner and PEDIS classifications as parameters to classify wounds' severity. Wagner's classification, despite of not covering crucial clinical scores for both the presence of ischemia and neuropathy, remains the most widely used in research and clinical practice, being elementary and easy to apply. The PEDIS classification was originally developed by the International Working Group on the Diabetic Foot (IWGDF) for research purposes, being more complex than the Wagner's one, and incorporating objective criteria of severity from a local and systemic infectious point of view. In this way, this becomes a useful tool to guide the empirical use of antimicrobials before obtaining the results of culture and antibiogram ${ }^{18}$.

In this study, there no patients with Wagner or PEDIS grades 0 and 1 , since we only included patients 
with infected diabetic foot that required hospitalization for surgery. There was predominance of grade 2 Wagner and grade 3 PEDIS injuries, slightly different from that found by Bona et al. ${ }^{12}$, in Ceara, and by Oliveira et al. ${ }^{19}$, in Goiania, who mostly observed more severe injuries (Wagner grade 4). A possible explanation for this difference is the easy access to urgent services in vascular surgery in the city of Manaus. As expected, we observed higher rates of amputations in the most severe degrees. Jeon et al. ${ }^{20}$, studying 158 patients with infected diabetic foot, also found a positive correlation between the degrees of severity and the rate of amputations.

In this study, we performed 105 culture tests of infected tissue fragments from diabetic feet, and in $95(90.5 \%)$ samples there was bacterial growth. The fact that there are negative results from tissue fragment cultures of lesions in which there was, clinically, the existence of infection, can be explained by technical failure in the collection of the material or in its culture seeding. The use of antibiotics before the collection of biological material can also be a less likely cause fot negatives cultures, since the culture came from a fragment of biological tissue. Unlike the studies by Mendes et al. ${ }^{21}$, Oliveira and Oliveira Filho ${ }^{9}$ and Xie et al. ${ }^{22}$, among the positive results, we found the growth of only one microorganism in each culture. This finding was probably due to the methodology adopted for culture. In this sense, we obtained only deep tissue biological material, the biopsy being performed after debridement and proper wound cleaning, thus reducing the possibility of contamination by superficial microorganisms and skin colonizers. We should note that this is a confirmation of the correct execution of the material collection method used.

As Oliveira and Oliveira Filho9, we found a higher prevalence of gram-negative bacteria (60.0\%), with a predominance of the Enterobacteriaceae family (51.5\%). Among these, we can highlight: Proteus mirabilis, Morganela morganii, Escherichia coli and Klesbisiella pneumoniae; there was a low frequency of Pseudomonas aeruginosa (4.2\%). These bacteria are often found in areas of hot climate ${ }^{23}$ and may be related both to climatic and to environmental and socio-cultural factors, as well as hygiene, among others ${ }^{24,25}$.

The predominant isolated strains in the wounds were S. aureus (20\%), followed by E. faecalis (17. 9\%), both Gram-positive cocci. Xie et al. ${ }^{22}$, studying 117 patients with infected diabetic foot, also predominantly found S. aureus and E. faecalis.

All E. faecalis isolated showed high levels of sensitivity to the different antibiotic classes. Shettigar et al. ${ }^{26}$, in a prospective epidemiological study with 100 patients, found $\mathrm{E}$. faecalis with high rates of resistance to antibiotics such as erythromycin (94\%), tetracyclines (91\%) and ciprofloxacin (89\%).

In the reference hospital in which we carried out the present study, the scheme of empirical antibiotics widely available and often used by the vascular surgeons is the association of ciprofloxacin and clindamycin, based on national clinical guidelines ${ }^{27}$. Vries et al. ${ }^{28}$ reported resistance for this combination by only $15 \%$ of $\mathrm{S}$. aureus and $22 \%$ of Gram-negative germs. In our series, we observed a high rate of $\mathrm{S}$. aureus resistant to clindamycin (63.2\%) and ciprofloxacin (55.5\%), only $56.5 \%$ of Gram-negative germs being sensitive to ciprofloxacin. Although these percentages refer to bacterial resistance demonstrated in vitro, these data point to the need to adapt the empirical antibiotic therapy initially used for the treatment of patients with infected diabetic foot at the studied Hospital. Provably, this is the most important evidence found in the present study.

There has been a constant concern about the increase in multidrug-resistant bacteria since the 90s, with great attention focused on the beta-lactamases or carbapenemases producing Gram-negative germs of the Enterobacteriaceae family, known as MDRO, emerging as one of the major problems in the treatment of infections in diabetic patients ${ }^{24,29}$. We isolated four strains of $\mathrm{K}$. pneumoniae and four of $\mathrm{E}$. coli that were multiresistant, with positive results for ESBL, corresponding to $14 \%$ of the isolated Gram-negative bacteria. All positive ESBL were sensitive to carbapenems, but resistant to the empirical scheme initially used. Sekhar et al. ${ }^{30}$, in a study with 108 patients hospitalized for the treatment of infected diabetic foot, observed a higher prevalence of MDRO in diabetic patients admitted with chronic foot injuries. These authors reported that the cultures of microorganisms such as E. coli, P. mirabillis and K. oxytoca, which that produce ESBL, also displayed high sensitivity to carbapenems. 
Among the 19 (20.0\%) cases of S. aureus, we found 12 (63.1\%) MRSA strains, thus observing a high frequency compared with Mendes et al. ${ }^{21}$, who found only $24.5 \%$ of MRSA. However, Mendes et al. ${ }^{21}$ studied only 49 patients, most of whom were treated on an outpatient basis, therefore with less severe injuries when compared with the injuries in the present study. We believe that the high frequency of MRSA we found may be due to frequent previous hospitalizations (51.4\%) and to previous use of antimicrobials (59.0\%).

Lauf et al. ${ }^{31}$ compared the use of ertapenem and tigecycline for the treatment of MRSA, with cure in $66 \%$ of patients treated with tigecycline of in $77 \%$ in those treated with ertapenem. In the present study, although ertapenem and tigecycline were not tested in MRSA, there was a $100 \%$ in vitro response to vancomycin, as well as to daptomycin, linezolid, teicoplanin and sulfamethoxazole-trimethoprim.

Our study's limitations were the lack of information on the time since the last hospitalization (in the cases of patients with previous in-hospital treatment) and not having explored which antibiotic regimens had been previously used (in those patients who had used them prior to hospitalization).

We conclude that, in the studied reference hospital, the sociodemographic characteristics of patients for the treatment of infected diabetic foot was mainly composed of men, aged 50 to 70 years, married, retired, with low level of education, and from the city of Manaus. There was a predominance of Gram-negative bacteria from the Enterobacteriaceae family. However, when analyzing the frequency of individual germs isolated, we observed that Staphylococcus aureus and E. faecalis, both Gram-positive cocci, were the most frequently isolated. Regarding the bacterial resistance, there were high rates of resistance of Gram-negative germs to ciprofloxacin and of methicillin-resistant $\mathrm{S}$. aureus, therefore also resistant to clindamycin. In view of this finding, we point out the need to adapt the initial empirical antibiotic therapy for patients with infected diabetic foot admitted to the Hospital 28 de Agosto. We therefore propose the association of vancomycin with a carbapenem or piperacillin-tazobactam as an initial empirical antibiotic therapy. Based upon our data, we further highlight the importance of cultures of tissue fragments of the foot lesions of these patients, associated with respective antibiograms, for the adequacy of antibiotic therapy during the treatment of this group of patients, always seeking to reduce the rates of amputations.

\title{
R E S U M O
}

\begin{abstract}
Objetivo: identificar o perfil sociodemográfico, microbiológico e de resistência bacteriana em pacientes com pé diabético infectado. Métodos: tratou-se de estudo observacional, transversal que avaliou os perfis sóciodemográfico e microbiológico de pacientes portadores de pé diabético infectado internados em Pronto Socorro de referência. Os dados sociodemográficos foram coletados por meio de entrevista. Foram colhidos, durante os procedimentos cirúrgicos, fragmentos de tecidos das lesões podais infectadas para realização de cultura/antibiograma. Resultados: a amostra foi composta por 105 pacientes. O perfil sociodemográfico mais prevalente foi o de pacientes do sexo masculino, acima dos 50 anos, casados e com baixa escolaridade. Das 105 amostras de fragmentos de tecidos colhidos para realização de cultura e antibiograma, 95 foram positivas, com crescimento de um único germe em cada um dos exames. Houve predomínio de germes da família Enterobacteriaceae (51,5\%). Germes Gram-negativos foram isolados em 60,0\% das culturas e os espécimes mais isolados individualmente foram os cocos Gram-positivos, Staphylococcus aureus $(20,0 \%)$ e Enterococcus faecalis $(17,9 \%)$. Considerando-se os perfis de resistência bacteriana, verificou-se alta taxa de Staphylococcus aureus resistente à meticilina (63,0\%) e à ciprofloxacino (55,5\%); verificou-se, também, que 43,5\% dos germes Gram-negativos eram resistentes à ciprofloxacino. Conclusões: o perfil sociodemográfico majoritário, foi o de homens, com mais de 50 anos e com baixa escolaridade. Concluímos que os germes mais prevalentes nas lesões podais dos pacientes diabéticos foram os Gram-negativos, resistentes ao ciprofloxacino e que o germe mais isolado individualmente foi o Staphylococcus aureus resistente à meticilina.
\end{abstract}

Palavras chave: Pé Diabético. Microbiota. Antibacterianos. Farmacorresistência Bacteriana.

\section{REFERENCES}

1. International Diabetes Federation. IDF Diabetes Atlas [livro eletrônico]. $8^{a}$ ed. 2017. [acesso em 18 jan 2020]. Disponível em: https://diabetesatlas.org/
upload/resources/previous/files/8/IDF_DA_8e-ENfinal.pdf

2. Lipsky BA. Diabetic foot infections: current treatment and delaying the 'post-antibiotic era'. Diabetes Metab Res Rev. 2016;32 Suppl 4:246-53. 
3. Rastogi A, Sukumar S, Hajela A, Mukkerjee S, Dutta $P$, Bhadada SK, Bhansali A. The microbiology of diabetic foot infections in patients recently treated with antibiotic therapy: A prospective study from India. J Diabetes Complications. 2017;31(2):407-12.

4. Rezende KF, Ferraz MB, Malerbi DA, Melo NH, Nunes MP, Pedrosa HC, Chacra AR Predicted annual costs for in patients with diabetes and foot ulcers in a developing country - a simulation of the current situation in Brazil. Diabet Med. 2010;27(1):109-12.

5. Ohki V, Galvão RC, Marques CG, Santos VP, Casteli Jr V, Caffari RA. Perfil microbiológico nas infecções profundas do pé diabético. Arq Med Hosp Fac Cienc Med Santa Casa São Paulo. 2010;55(1):157. [acesso em 18 jan 2020]. Disponível em: http:// arquivosmedicos.fcmsantacasasp.edu.br/index.php/ AMSCSP/article/view/306/321

6. Pence LM, Mock, CM, Kays MB, Damer KM, Muloma EW, Erdan SM. Correlation of adherence to the 2012 Infectious Diseases Society of America practice guidelines with patient outcomes in the treatment of diabetic foot infections in an outpatient parenteral antimicrobial programme. Diabet Med. 2014;31(9):1114-20.

7. Sonmerzer MC, Tulek N, Ozsoy M, Erdinc F, Ertem $G$. Diabetic foot infections: effective microorganisms and factors affecting the frequency of osteomyelitis and amputation. European Res J. 2015;1(3):119-27.

8. Hatipoglu M, Mutluoglu M, Karabacak E, Turhan $\mathrm{V}$, Lipsky BA. The microbiologic profile of diabetic foot infections in Turkey: a 20-year systematic review: diabetic foot infections in Turkey. Eur J Clin Microbiol Infect Dis. 2014;33(6):871-8.

9. Oliveira AF, Oliveira Filho H. Perfil microbiológico e de resistência antimicrobiana no pé diabético infectado. J Vasc Bras. 2014;13(4):289-93.

10. Sotto A, Richard JL, Combescure C, Jourdan N, Schuldiner S, Bouziges N, Lavigne J-P. Beneficial effects of implementing guidelines on microbiology and costs of infected diabetic foot ulcers. Diabetologia. 2010;53(10):2249-55.

11. Lipsky BA, Berendt AR, Cornia PB, Pile JC, Peters EJG, Armstrong DG, et al. Infectious Diseases Society of America clinical practice guideline for the diagnosis and treatment of diabetic foot infections. Clin Infect
Dis. 2012;54(12):132-73.

12. Bona SF, Barbosa MAR, Ferraz CLH, Guarita LKS, Nina RVAH, Brabosa NMRF, et al. Prevalência do pé diabético nos pacientes atendidos na emergencia de um hospital público terciário de Fortaleza. Rev Bras Clin Med. 2010;8(1):1-5. [acesso em 18 jan 2020]. Disponível em http://files.bvs.br/ upload/S/1679-1010/2010/v8n1/a001.pdf

13. Pedras $S$, Carvalho R, Pereira MG. Sociodemographic and clinical characteristics of patients with diabetic foot ulcer. Rev Assoc Med Bras. 2016;62(2):171-8.

14. Berardis GD, Pellegrini F, Franciosi M, Nardo B, Greenfileld S, Kaplan SH, et al. Are type 2 diabetic patients offered adequate foot care? The role of physician and patient characteristics. J Diabetes Complications. 2005;19(6):319-27.

15. Malachias MVB, Souza WKSB, Plavnik FL, Rodrigues CIS, Brandão AA, Neves MFT, et al. 7a diretriz brasileira de hipertensão arterial. Arq Bras Cardiol. 2016;107(3):1-103. [acesso em 18 jan 2020]. Disponível em: http://www.scielo.br/pdf/abc/ v107n3s3/pt_0066-782X-abc-107-03-s3-0001.pdf

16. Hinchliffe RF, Brownrigg JRW, Apelqvist J, Boyko EJ, Fitridge R, Mills JL, Reekers J, Shearman CP, Zierler $R E$, Schaper NC, International Working Group on the Diabetic Foot. IWGDF guidance on the diagnosis, prognosis and management of peripheral artery disease in patients with foot ulcers in diabetes. Diabetes Metab Res Rev. 2016;32 Suppl 1:37-44.

17. Schaper NC, Andros G, Apelqvist J, Bakker K, Lammer J, Lepantalo $M$, et al. Diagnosis and treatment of peripheral arterial disease in diabetic patients with a foot ulcer. A progress report of the International Working Group on the Diabetic Foot. Diabetes Metab Res Ver. 2012;28 Suppl 1:218-24.

18. Ghotaslou R, Memar MY, Alizadeh N. Classification, microbiology and treatment of diabetic foot infections. J Wound Care. 2018;27(7):434-41.

19. Oliveira JC, Taquary SAS, Barbosa AM, Veronezi RJB. Pé diabético: perfil sociodemográfico e clínico de pacientes hospitalizados. Rev Bras Ciênc Saúde. 2018;22(1):15-20.

20. Jeon BJ, Choi HJ, Kang JS, Tak MS, Park ES. Comparison of five systems of classification of diabetic foot ulcers and predictive factors for 
amputation. Int Wound J. 2017;14(3):537-45.

21. Mendes JJ, Marques-Costa A, Vilela C, Neves J, Candeias N, Cavaco-Silva $P$, et al. Clinical and bacteriological survey of diabetic foot infections in Lisbon. Diabetes Res Clin Pract. 2012;95(1):153-61.

22. Xie $X$, Bao Y, Ni L, Liu D, Niu S, Lin H, et al. Bacterial profile and antibiotic resistance in patients with diabetic foot ulcer in Guangzhou, southern China: focus on the differences among different wagner's grades, IDSA/IWGDF grades, and ulcer types. Int J Endocrinol. 2017;2017:8694903.

23. Uçkay I, Gariani K, Pataky Z, Lipsky BA. Diabetic foot infections: state-of-the-art. Diabetes Obes Metab. 2014;16(4):305-16.

24. Peters EJ, Lipsky BA. Diagnosis and management of infection in the diabetic foot. Med Clin North Am. 2013;97(5):911-946.

25. Bakker K, Apelqvist J, Lipsky BA, Van Netten JJ; International Working Group on the Diabetic Foot. The 2015 IWGDF guidance documents on prevention and management of foot problems in diabetes: development of an evidence-based global consensus. Diabetes Metab Res Rev. 2016;32 Suppl 1:2-6.

26. Shettigar K, Bhat DV, Satyamoorthy K, Murali TS. Severity of drug resistance and co-existence of

Received in: 26/01/2020

Accepted for publication: 19/03/2020

Conflict of interest: no.

Funding source: none.
Enterococcus faecalis in diabetic foot ulcer infections. Folia Microbiol (Praha). 2018;63(1):115-122.

27. Levin AAS. Guia de utilização de anti-infecciosos e recomendações para a prevenção de infecções relacionadas à assistência à saúde [internet]. 7.ed. São Paulo: Hospital da Clínicas; 2014. [acesso em 18 jan 2020]. Disponível em: https://www.sbp.com.br/ fileadmin/user_upload/pdfs/Anti-Infecciosos_Infec Hospitalar.pdf

28. Vries MG, Ekkelenkamp MB, Peters EJ. Are clindamycin and ciprofloxacin appropriate for the empirical treatment of diabetic foot infections? Eur J Clin Microbiol Infect Dis. 2014;33(3):453-456.

29. Boyanova L, Mitov I. Antibiotic resistance rates in causative agents of infections in diabetic patients: rising concerns. Expert Rev Anti Infect Ther. 2013;11(4):411-420.

30. Sekhar S, Vyas N, Unnikrishnan M, Rodrigues G, Mukhopadhyay C. Antimicrobial susceptibility pattern in diabetic foot ulcer: a pilot study. Ann Med Health Sci Res. 2014;4(5):742-745.

31. Lauf L, Ozsvár Z, Mitha I, Regöly-Mérei J, Embil JM, Cooper A, et al. Phase 3 study comparing tigecycline and ertapenem in patients with diabetic foot infections with and without osteomyelitis. Diagn Microbiol Infect Dis. 2014;78(4):469-480.
Mailing address:

Leonardo Pessoa Cavalcante

E-mail: leonardocavalcante@usp.br

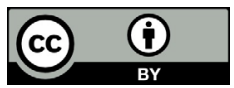




\section{Erratum}

The article "Microbiologic characteristics and antibiotic resistance rates of diabetic foot infections", DOI number: 10.1590/0100-6991e-20202471, published in the Journal of the Brazilian College of Surgeons. 47(1);e20202471.
Where it is:

Funding source: none.

\section{It should be:}

Funding source: Fundação de Amparo à Pesquisa do Estado do Amazonas (EDITAL N. 005/2019 PAPAC). 